\title{
Austenitic stainless steel bismuth-free flux-cored wires for high-temperature applications
}

\author{
Elin M. Westin ${ }^{1}$ - Ronald Schnitzer ${ }^{1,2} \cdot$ Francesco Ciccomascolo $^{3}$. \\ Andrea Maderthoner ${ }^{1}$ • Kaj Grönlund ${ }^{4}$ • Gunilla Runnsjö ${ }^{4}$
}

Received: 26 February 2016 / Accepted: 8 August 2016 / Published online: 29 August 2016

(C) The Author(s) 2016. This article is published with open access at Springerlink.com

\begin{abstract}
Since the 1970s, bismuth is widely used as an auxiliary ingredient in stainless steel flux-cored wires to improve slag detachability. But, for components subject to post-weld heat treatment (PWHT) and/or applications at high temperature, bismuth has been confirmed to have a negative effect on weld metal ductility. It has been suggested that this is due to grain boundary bismuth segregation, and it has been debated whether it is as bismuth or as bismuth oxide $\mathrm{Bi}_{2} \mathrm{O}_{3}$. There are also reports on cracks found in weldments after service at elevated temperatures. This has affected the specifications, and API RP 582 has included a maximum bismuth content of $20 \mathrm{ppm}$ in the weld deposit when welding with austenitic stainless steel flux-cored wires for applications above $538{ }^{\circ} \mathrm{C}$, including PWHT. This demand required development of a range of flux-cored wires intended for overlay welding (cladding) of creepresistant steels and joining stainless steels for hightemperature applications. Standard E347, E309L and $\mathrm{E} 308 \mathrm{H}$ wires have here been compared with bismuth-
\end{abstract}

Recommended for publication by Commission IX - Behaviour of Metals Subjected to Welding

Elin M. Westin

elin.westin@voestalpine.com

1 voestalpine Böhler Welding Austria GmbH, Böhler-Welding-St. 1, 8605 Kapfenberg, Austria

2 Department of Physical Metallurgy and Materials Testing, Montanuniversitaet Leoben, Franz-Josef-Strasse 18, 8700 Leoben, Austria

3 voestalpine Böhler Welding GmbH, Peter-Müller-St. 14-14a, 40468 Düsseldorf, Germany

4 Corr-Control, Älvbrovägen 54, 77435 Avesta, Sweden free versions in as-welded condition and after PWHT. All-weld metal has been subject to mechanical, hot ductility and Varestraint testing. Results show that bismuthfree wires have higher ductility, and this was confirmed also when welding in single V-butt weld joints. Electron microprobe analysis (EPMA) modified for high precision mapping is used to illustrate that bismuth has a particle-like distribution without any clear relation to oxygen.

Keywords (IIW Thesaurus) FCA welding · Austenitic stainless steels $\cdot$ Core filler wire $\cdot$ FCA surfacing $\cdot$ High temperature $\cdot$ Post-weld heat treatment $\cdot$ Bismuth $\cdot$ Mechanical properties

\section{Introduction}

Flux-cored arc welding (FCAW) results in good surface finishes, which makes post-fabrication cleaning easier when welding stainless steel. As the parameter box is wide, the method is welder friendly. The productivity is higher than in gas metal arc welding (GMAW) with higher deposition rates, and this can reduce the total welding costs considerably. Furthermore, pulsing is not necessary. As compared with GMAW, the wide arc in FCAW provides uniform, deep penetration and improved sidewall fusion. This reduces the risk of weld defects (lack of fusion). There is also less risk of spatter and porosity. In addition, the shielding gas costs are lower than in GMAW. Optimal weldability and mechanical properties are achieved using $\mathrm{Ar}+$ $18-25 \% \mathrm{CO}_{2}$, but some fabricators prefer $100 \% \mathrm{CO}_{2}$ to reduce gas costs. FCAW is frequently used for general fabrication and on-site welding of stainless steel.

By optimisation of the flux in cored wire, it is possible to enable deoxidation of the weld metal, form slag, stabilise the 
arc and add metal powder. This in turn influences the welding characteristics, deposition rates and mechanical properties. The slag concept also determines in which position the material can be used for welding. AWS T0 types are suitable for welding in the flat/horizontal position and overlay welding (cladding). AWS T1 types feature a fast-freezing slag system supporting the weld pool when welding in all positions. These wires are, for instance, used for welding pipes in fixed position.

Modern austenitic stainless steel FCAW wires contain a small amount of bismuth oxide $\left(\mathrm{Bi}_{2} \mathrm{O}_{3}\right)$ for improved slag detachability and to produce a clean toe line, especially in fillet welds [1]. The weld deposit typically contains 0.02 wt.\% bismuth (200 ppm), and there have been reports of intergranular cracking and premature creep failure in such weldments after a period of service at $650-750{ }^{\circ} \mathrm{C}[2-4]$. Different fractographic studies have shown the presence of bismuth or bismuth oxide on the surface of fractured creep specimens $[5,6]$. The vast majority of stainless steel weld deposits are put into service below about $250{ }^{\circ} \mathrm{C}\left(480{ }^{\circ} \mathrm{F}\right)$, but within power generation and process industries, extended service can exceed temperatures of $480^{\circ} \mathrm{C}\left(900^{\circ} \mathrm{F}\right)$ [7]. It is in these latter weldments that bismuth can cause problems. Cracking could theoretically also occur when carrying out a post-weld heat treatment (PWHT) when weld overlaying carbon steel or after repair of castings. Critical process equipment in refineries such as heavy-wall reactors or pressure vessels for hydrotreating and hydrocracking is normally made in lowalloyed creep-resistant steels, i.e. $1 \frac{1}{4} \mathrm{Cr}-0.5 \mathrm{Mo}, 2 \frac{1}{4} 4 \mathrm{Cr}-1 \mathrm{Mo}$, $2 \frac{1}{4} \mathrm{Cr}-1 \mathrm{MoV}$ and clad internally with alloy 347 . Some areas such as the inside of nozzles and fittings cannot be covered by clad plates and/or strip cladding and need separate overlay welding. This can be efficiently done using the FCAW process with an E309L buffer layer between the creep-resistant steel and the E347 layer. This type of equipment is typically operated at temperatures below $500{ }^{\circ} \mathrm{C}$, but depending on the alloy grade and requirements on mechanical properties, a final PWHT is performed at $660-710^{\circ} \mathrm{C}$, in addition to other intermediate PWHT. Thus, the weld overlay deposit is exposed to temperatures where bismuth-alloying may cause cracking. FCAW overlay welding is also performed using E308H. One application is restoration of fluid catalytic cracking (FCC) regenerators that operate at temperatures above $700{ }^{\circ} \mathrm{C}$. At these temperatures, bismuth segregates in the grain boundaries and failure cases reported in the literature often refer to FCC regenerator equipment [3].

Once the detrimental effect of bismuth on hightemperature properties had been recognised, it is understood that some end user plant operators placed a complete ban on the use of FCAW for certain critical applications [1]. Today, there are stainless steel FCAW wires without bismuth (less than $20 \mathrm{ppm}$ ) whose deposits do not exhibit heat cracking or premature creep failure. Weld metals deposited from bismuth-free FCAW wires have been shown to have high-temperature creep properties on par with those made with other welding processes and consumables [8]. Konosu et al. [6] carried out creep tests at $650{ }^{\circ} \mathrm{C}$ on type E308 FCAW weld metal with $230 \mathrm{ppm}$ bismuth and compared these with bismuth-free FCAW and SMAW deposits. It was concluded that FCAW wire alloyed with bismuth caused segregation of bismuth in the grain boundaries and that this was harmful with respect to creep ductility and creep crack growth properties. There was no large difference in creep fracture elongation between the SMAW and FCAW weld metals both of which contained no bismuth.

The American Petroleum Institute (API) has incorporated a limit of $20 \mathrm{ppm}$ bismuth in austenitic stainless steel FCAW deposits in API RP 582 'Welding Guidelines for the Chemical, Oil, and Gas Industries' [9] when these weld metals are exposed to temperatures above $1000^{\circ} \mathrm{F}\left(538^{\circ} \mathrm{C}\right)$ during fabrication and/or during service. AWS A5.22/A5.22M:2012 [10] states that stainless steel electrodes containing bismuth additions should not be used for such high temperature services or PWHT above about $900^{\circ} \mathrm{F}\left(500^{\circ} \mathrm{C}\right)$. Instead stainless steel flux-cored electrodes providing no more than $20 \mathrm{ppm}$ $(0.002$ wt. \%) bismuth in the weld metal should be specified. These wires are promoted by manufacturers as bismuth-free.

Farrar et al. [1] performed a round robin within IIW Commission IX-H where nine laboratories from six countries analysed the bismuth content of weld deposits from two stainless steel flux-cored wires - one with deliberate additions of bismuth oxide and one without. The bismuth content in the bismuth-free sample was reported to be $0.6-20 \mathrm{ppm}$, and this reflects the detection limit. On the basis of these results, a practical threshold limit of less than $20 \mathrm{ppm}$ seems acceptable for the specification of 'bismuth-free' weld metal.

The increased need for bismuth-free flux-cored wires for high-temperature applications motivates evaluation and optimisation of existing products for joining and cladding. Besides maintaining the mechanical properties at elevated temperatures, the aim is to ensure as good welding characteristics and slag detachability as for the standard FCAW wires containing bismuth. By comparing the bismuth-free versions with the standard products, it is possible to determine which effect bismuth has on the properties in as-welded condition and after PWHT. In addition, the objective is to clarify if bismuth segregates at the grain boundaries as bismuth or bismuth oxide $\mathrm{Bi}_{2} \mathrm{O}_{3}$. 


\section{Experimental}

The composition of the filler metals used in this work and the measured ferrite number are shown in Table 1.

To improve the slag removal, the bismuth-free versions have another slag concept with other levels of elements and minerals as compared with the standard wires. The T1 type E 347 H PW-FD has intentionally higher carbon content as the main application for this wire would be joining and there is a typical industry requirement that the carbon content should exceed 0.04 wt.\%. For cladding applications, the T0 type E 347L H-FD has lower carbon content as typical industrial solutions result in about $0.03 \mathrm{wt} . \%$ in the final layer.

All-weld metal samples were prepared in accordance with EN 15792-1:2012 using $\mathrm{Ar}+18 \% \mathrm{CO}_{2}$ as shielding gas. The samples were either left in aswelded condition or underwent PWHT following the Godrej specification WCPS/130,615-130,641 [11]. The heating rate was $85{ }^{\circ} \mathrm{C} / \mathrm{h}$ from $300{ }^{\circ} \mathrm{C}$, the temperature 600-800 ${ }^{\circ} \mathrm{C}$ and holding time $8-48 \mathrm{~h}$. The welded samples were subject to tensile and charpy $\mathrm{V}$ impact toughness testing (DIN EN 1591-1/Form 3). The tensile tests were carried out on single specimens and impact testing on three samples for improved statistics. The mechanical properties of actual joints were also determined using $20 \mathrm{~mm}$ thick base material prepared as single V-butt weld joints with $60^{\circ}$ opening angle, $1.5 \mathrm{~mm}$ unbeveled edge and $4 \mathrm{~mm}$ gap. It was filled with 6 layers and in total $10-11$ weld beads. The shielding gas was $\mathrm{Ar}+$ $18 \% \mathrm{CO}_{2}$ and interpass temperature $150{ }^{\circ} \mathrm{C}$. The welding parameters are given in Table 2 .
The bismuth distribution in all-weld metal was determined in SAS 2-FD and Bi-free E 347L H-FD after PWHT for $40 \mathrm{~h}$ at $705^{\circ} \mathrm{C}$. Mapping was performed on polished cross-sections of all weld metal using a modified electron probe microanalysis (EPMA) instrument (ARL-SEMQ, DELL GX1-500) [12]. The instrument contained six wavelength dispersive spectrometers modified for mapping, each equipped with two monochromator crystals (of type LiF, ADP, TAP, PET and a multilayer crystal of type $\mathrm{NiC}$ for long wavelengths related to light elements). This enabled determination of manganese, nickel, oxygen, chromium, bismuth and niobium contents simultaneously. As this is a niobium-stabilised alloy, the distribution of niobium was studied to ensure that there are no disturbing wavelength effects between bismuth and niobium. Calibration was performed using the base material and a set of NBS reference materials. The operating conditions were $6000 \mathrm{nA}$ sample current, $25 \mathrm{kV}$ accelerating voltage and $1 \mu \mathrm{m}$ beam diameter. Chemical mapping (comprising 10,000 analyses per element and specimen) was carried out moving the sample stage in $1 \times 1 \mu \mathrm{m}$ steps for detailed information on the microstructural distribution of the elements.

Hot tensile testing was performed at 500, 700 and $800{ }^{\circ} \mathrm{C}$ in accordance with EN ISO 6892-2:2011. The samples were welded with $100{ }^{\circ} \mathrm{C}$ preheating and $150{ }^{\circ} \mathrm{C}$ interpass temperature. The shielding gas was $\mathrm{Ar}+18 \% \mathrm{CO}_{2}$ and the gas flow $17 \mathrm{l} / \mathrm{min}$. The base material was $20 \mathrm{~mm}$ thick Grade S $235 \mathrm{JR}$. The sides were buffered with two layers. The opening angle was $20^{\circ}$, and the root opening $16 \mathrm{~mm}$. It was filled with 7 layers and in total $15-16$ weld beads. The welding parameters are given in Table 3 . The fracture samples
Table 1 Chemical composition of all-weld metal (wt.\%)

\begin{tabular}{lllllllllr}
\hline Filler & AWS & C & Si & Mn & Cr & Ni & Mo & Nb & FN $^{\mathrm{a}}$ \\
\hline SAS 2-FD & E347T0 & 0.030 & 0.53 & 1.67 & 19.58 & 10.60 & 0.04 & 0.370 & 7.2 \\
E 347L H-FD & E347T0 & 0.030 & 0.63 & 1.58 & 18.61 & 10.45 & 0.04 & 0.500 & 6.7 \\
SAS 2 PW-FD & E347T1 & 0.024 & 0.69 & 1.43 & 19.35 & 10.28 & 0.05 & 0.340 & 8.0 \\
SAS 2 PW-FD (LF) & E347T1 & 0.022 & 0.73 & 1.42 & 19.22 & 10.60 & 0.08 & 0.440 & 6.1 \\
E 347 H PW-FD & E347HT1 & 0.044 & 0.71 & 1.46 & 18.52 & 10.55 & 0.08 & 0.424 & 6.1 \\
CN 23/12-FD & E309LT0 & 0.024 & 0.67 & 1.43 & 22.65 & 12.35 & 0.07 & 0.004 & 17.6 \\
E 309L H-FD & E309LT0 & 0.030 & 0.56 & 1.47 & 23.16 & 13.00 & 0.05 & 0.012 & 14.8 \\
CN 23/12 PW-FD & E309LT1 & 0.027 & 0.72 & 1.53 & 22.91 & 12.41 & 0.05 & 0.006 & 20.4 \\
E 309L H PW-FD & E309LT1 & 0.032 & 0.65 & 1.31 & 23.30 & 12.29 & 0.02 & 0.006 & 18.2 \\
E 308 H PW-FD & E308HT1 & 0.053 & 0.70 & 1.43 & 19.69 & 10.56 & 0.05 & 0.003 & 6.7 \\
\hline
\end{tabular}

All wires had a diameter of $1.2 \mathrm{~mm}$. The standard wires had a bismuth content of $180 \mathrm{ppm}$. All wires with an ' $\mathrm{H}$ ' in the product name are bismuth-free $(0.001 \mathrm{wt} . \%$ max $)$

${ }^{\mathrm{a}}$ Ferrite measured with Fischer FeritScope MP30

${ }^{\mathrm{b}}$ Low ferrite version for improved impact toughness at cryogenic temperatures 
Table 2 Welding parameters for single V-butt weld joints

\begin{tabular}{lllll}
\hline Filler & Base metal & $\mathrm{I}(\mathrm{A})$ & $\mathrm{U}(\mathrm{V})$ & Wire feed speed (m/min) \\
\hline SAS 2 PW-FD & 1.4550 & 245 & 30.7 & 11.0 \\
E 347 H PW-FD & 1.4550 & 250 & 28.0 & 11.0 \\
CN 23/12 PW-FD & $1.4541 / \mathrm{S} 355 \mathrm{~N}$ & 250 & 30.5 & 11.0 \\
E 309L H PW-FD & $1.4541 / \mathrm{S} 355 \mathrm{~N}$ & 241 & 27.9 & 11.1 \\
\hline
\end{tabular}

Table 3 Welding parameters for samples used for hot tensile testing

\begin{tabular}{llllll}
\hline Filler & $\begin{array}{l}\mathrm{I} \\
(\mathrm{A})\end{array}$ & $\begin{array}{l}\mathrm{U} \\
(\mathrm{V})\end{array}$ & $\begin{array}{l}\text { Welding speed }(\mathrm{mm} / \\
\mathrm{min})\end{array}$ & $\begin{array}{l}\text { Heat input }(\mathrm{kJ} / \\
\mathrm{mm})\end{array}$ & $\begin{array}{l}\text { Wire feed speed } \\
(\mathrm{m} / \mathrm{min})\end{array}$ \\
\hline CN 23/12-FD & 225 & 28.8 & 296 & 1.30 & 11.0 \\
E 309L H-FD & 225 & 28.9 & 300 & 1.29 & 11.0 \\
SAS 2-FD & 220 & 28.4 & 285 & 1.31 & 10.4 \\
E 347L H-FD & 215 & 28.3 & 295 & 1.21 & 11.0 \\
E 308H PW- & 230 & 27.0 & 340 & 1.10 & 12.0 \\
$\quad$ FD & & & & & \\
\hline
\end{tabular}

Table 4 Parameters for Varestraint testing

\begin{tabular}{|c|c|c|c|c|c|c|}
\hline \multirow[t]{2}{*}{ All-weld metal } & \multirow[t]{2}{*}{ PWHT } & \multicolumn{2}{|c|}{ Bend parameters } & \multicolumn{3}{|c|}{ Welding parameters } \\
\hline & & Radius (mm) & Strain $(\%)$ & $\mathrm{I}(\mathrm{A})$ & $\mathrm{U}(\mathrm{V})$ & Heat input $(\mathrm{kJ} / \mathrm{mm})$ \\
\hline SAS 2-FD & None & 500 & 1 & 188.5 & 12.9 & 0.81 \\
\hline SAS 2-FD & None & 250 & 2 & 188.5 & 13.3 & 0.84 \\
\hline SAS 2-FD & None & 125 & 4 & 189.5 & 13.5 & 0.85 \\
\hline SAS 2-FD & $705^{\circ} \mathrm{C}$ for $40 \mathrm{~h}$ & 500 & 1 & 188.5 & 12.9 & 0.81 \\
\hline SAS 2-FD & $705^{\circ} \mathrm{C}$ for $40 \mathrm{~h}$ & 250 & 2 & 188.6 & 13.2 & 0.83 \\
\hline SAS 2-FD & $705^{\circ} \mathrm{C}$ for $40 \mathrm{~h}$ & 125 & 4 & 189.1 & 13.4 & 0.84 \\
\hline E 347L H-FD & None & 500 & 1 & 188.4 & 12.7 & 0.80 \\
\hline E 347L H-FD & None & 250 & 2 & 188.5 & 13.0 & 0.82 \\
\hline E 347L H-FD & None & 125 & 4 & 189.0 & 13.1 & 0.83 \\
\hline E 347L H-FD & $705^{\circ} \mathrm{C}$ for $40 \mathrm{~h}$ & 500 & 1 & 188.4 & 12.7 & 0.80 \\
\hline E 347L H-FD & $705^{\circ} \mathrm{C}$ for $40 \mathrm{~h}$ & 250 & 2 & 188.5 & 12.9 & 0.81 \\
\hline E 347L H-FD & $705^{\circ} \mathrm{C}$ for $40 \mathrm{~h}$ & 125 & 4 & 188.8 & 13.1 & 0.82 \\
\hline
\end{tabular}

Table 5 Mechanical properties of E347 type all-weld metal in as-welded condition ( $\mathrm{Z}$ is the reduction of area)

\begin{tabular}{|c|c|c|c|c|c|c|c|c|c|c|}
\hline \multirow[t]{2}{*}{ Filler } & \multicolumn{4}{|l|}{ Tensile test } & \multicolumn{3}{|c|}{ Impact toughness $(\mathrm{J})$} & \multicolumn{3}{|c|}{ Lateral expansion (mm) } \\
\hline & $\mathrm{Rp}_{0.2}(\mathrm{MPa})$ & $\mathrm{Rm}(\mathrm{MPa})$ & $\mathrm{A}_{5}(\%)$ & $\mathrm{Z}(\%)$ & $20^{\circ} \mathrm{C}$ & $-120^{\circ} \mathrm{C}$ & $-196^{\circ} \mathrm{C}$ & $20{ }^{\circ} \mathrm{C}$ & $-120^{\circ} \mathrm{C}$ & $-196^{\circ} \mathrm{C}$ \\
\hline SAS 2-FD & 426 & 585 & 40.7 & 49.3 & $80 \pm 1$ & $41 \pm 3$ & $32 \pm 2$ & $1.49 \pm 0.03$ & $0.70 \pm 0.04$ & $0.60 \pm 0.03$ \\
\hline E 347L H-FD & 423 & 591 & 40.8 & 53.9 & $95 \pm 1$ & $55 \pm 2$ & $40 \pm 2$ & $1.64 \pm 0.07$ & $0.77 \pm 0.02$ & $0.57 \pm 0.04$ \\
\hline SAS 2 PW-FD & 424 & 592 & 35.0 & 52.0 & $73 \pm 2$ & $40 \pm 4$ & $32 \pm 2$ & $1.53 \pm 0.05$ & $0.71 \pm 0.04$ & $0.48 \pm 0.05$ \\
\hline E 347 H PW-FD & 423 & 592 & 39.3 & 57.8 & $100 \pm 5$ & $56 \pm 4$ & $38 \pm 2$ & $1.89 \pm 0.01$ & $0.95 \pm 0.04$ & $0.54 \pm 0.04$ \\
\hline
\end{tabular}

$\mathrm{A}_{5}$ is calculated with original diameter $d_{0}=10 \mathrm{~mm}$ 
Table 6 Mechanical properties of E309L type all-weld metal in as-welded condition
Table 7 Mechanical properties resulting from the hot tensile test

\begin{tabular}{|c|c|c|c|c|c|c|}
\hline \multirow[t]{2}{*}{ Filler } & \multicolumn{4}{|l|}{ Tensile test } & \multicolumn{2}{|c|}{ Impact toughness $(\mathrm{J})$} \\
\hline & $\mathrm{Rp}_{0.2}(\mathrm{MPa})$ & $\mathrm{Rm}(\mathrm{MPa})$ & $\mathrm{A}_{5}(\%)$ & $\mathrm{Z}(\%)$ & $20^{\circ} \mathrm{C}$ & $-60{ }^{\circ} \mathrm{C}$ \\
\hline CN 23/12-FD & 400 & 529 & 37.3 & 48.4 & $48 \pm 3$ & $43 \pm 3$ \\
\hline E 309L H-FD & 402 & 542 & 40.4 & 56.0 & $69 \pm 4$ & $51 \pm 4$ \\
\hline CN 23/12 PW-FD & 399 & 532 & 37.1 & 50.3 & $60 \pm 8$ & $45 \pm 2$ \\
\hline E 309L H PW-FD & 398 & 535 & 40.3 & 48.0 & $82 \pm 4$ & $64 \pm 2$ \\
\hline
\end{tabular}

\begin{tabular}{lllllll}
\hline Filler & Temp. $\left({ }^{\circ} \mathrm{C}\right)$ & $\mathrm{Rp}_{0.2}(\mathrm{MPa})$ & $\mathrm{Rm}(\mathrm{MPa})$ & $\mathrm{A}_{5}(\%)$ & $\mathrm{Z}(\%)$ & Failure location $^{\mathrm{a}}$ \\
\hline SAS 2-FD & 500 & 304 & 415 & 27.2 & 52.6 & 1 \\
SAS 2-FD & 700 & 238 & 307 & 22.9 & 29 & 1 \\
E 347L H-FD & 500 & 307 & 419 & 26.4 & 56.6 & 1 \\
E 347L H-FD & 700 & 246 & 301 & 30.1 & 45 & 2 \\
CN 23/12-FD & 700 & 174 & 244 & 18.4 & 23.8 & 2 \\
E 309L H-FD & 700 & 180 & 249 & 38.9 & 48.2 & 2 \\
E 308 H PW-FD & 700 & 223 & 186 & 42.7 & 51.1 & 1 \\
E 308 H PW-FD & 800 & 151 & 133 & 34.0 & 41.9 & 1 \\
\hline
\end{tabular}

${ }^{a}$ Failure location 1 means that the fracture was inside the middle half of the reduced section. Location 2 means that the fracture occurred where the distance between fracture and nearest gauge mark was less than $25 \%$

Table 8 Mechanical properties before and after PWHT at $700{ }^{\circ} \mathrm{C}$

\begin{tabular}{|c|c|c|c|c|c|c|c|c|c|c|c|}
\hline \multirow[t]{2}{*}{ Filler } & \multirow[t]{2}{*}{ PWHT } & \multicolumn{4}{|l|}{ Tensile test } & \multicolumn{3}{|c|}{ Impact toughness $(\mathrm{J})$} & \multicolumn{3}{|c|}{ Lateral expansion (mm) } \\
\hline & & $\mathrm{Rp}_{0.2}(\mathrm{MPa})$ & $\mathrm{Rm}(\mathrm{MPa})$ & $\mathrm{A}_{5}(\%)$ & $\mathrm{Z}(\%)$ & $20{ }^{\circ} \mathrm{C}$ & $-120^{\circ} \mathrm{C}$ & $-196^{\circ} \mathrm{C}$ & $20^{\circ} \mathrm{C}$ & $-120^{\circ} \mathrm{C}$ & $-196^{\circ} \mathrm{C}$ \\
\hline SAS 2-FD & None & 426 & 585 & 40.7 & 49.3 & $80 \pm 1$ & $41 \pm 3$ & $32 \pm 2$ & $1.49 \pm 0.03$ & $0.70 \pm 0.04$ & $0.60 \pm 0.03$ \\
\hline SAS 2-FD & $8 \mathrm{~h}$ & 412 & 611 & 36.8 & 51.7 & $64 \pm 5$ & $19 \pm 2$ & $14 \pm 2$ & $1.25 \pm 0.04$ & $0.42 \pm 0.03$ & $0.34 \pm 0.02$ \\
\hline SAS 2-FD & $36 \mathrm{~h}$ & 427 & 646 & 31.1 & 41.1 & $36 \pm 3$ & $12 \pm 1$ & $13 \pm 1$ & $0.78 \pm 0.11$ & $0.24 \pm 0.02$ & $0.29 \pm 0.05$ \\
\hline SAS 2-FD & $48 \mathrm{~h}$ & 415 & 634 & 35.9 & 42.2 & $34 \pm 1$ & $12 \pm 2$ & $12 \pm 2$ & $0.78 \pm 0.04$ & $0.20 \pm 0.08$ & $0.26 \pm 0.03$ \\
\hline E 347L H-FD & None & 416 & 582 & 40.4 & 54.6 & $86 \pm 1$ & $48 \pm 2$ & $41 \pm 2$ & $1.44 \pm 0.17$ & $0.79 \pm 0.01$ & $0.68 \pm 0.02$ \\
\hline E 347L H-FD & $8 \mathrm{~h}$ & 415 & 614 & 38.1 & 50.6 & $66 \pm 3$ & $22 \pm 5$ & $18 \pm 1$ & $1.20 \pm 0.07$ & $0.47 \pm 0.07$ & $0.42 \pm 0.02$ \\
\hline E 347L H-FD & $36 \mathrm{~h}$ & 425 & 641 & 38.7 & 41.9 & $37 \pm 3$ & $14 \pm 2$ & $14 \pm 3$ & $0.83 \pm 0.09$ & $0.26 \pm 0.01$ & $0.31 \pm 0.04$ \\
\hline E 347L H-FD & $48 \mathrm{~h}$ & 418 & 644 & 31.8 & 42.8 & $37 \pm 2$ & $13 \pm 2$ & $13 \pm 1$ & $0.89 \pm 0.04$ & $0.21 \pm 0.01$ & $0.29 \pm 0.04$ \\
\hline
\end{tabular}

Table 9 Mechanical properties before and after PWHT at $700{ }^{\circ} \mathrm{C}$

\begin{tabular}{lllllll}
\hline Filler & PWHT & \multicolumn{2}{l}{ Tensile test } & & \multirow{2}{*}{ Ferrite } \\
\cline { 3 - 5 } & & & $\mathrm{Rp}_{0.2}(\mathrm{MPa})$ & $\mathrm{Rm}(\mathrm{MPa})$ & $\mathrm{A}_{5}(\%)$ & $\mathrm{Z}(\%)$ \\
\hline SAS 2 PW-FD & None & 408 & 577 & 39.8 & 61.5 & $8.0-9.5$ \\
SAS 2 PW-FD & $8 \mathrm{~h}$ & 415 & 602 & 34.0 & 54.2 & $4.0-5.1$ \\
SAS 2 PW-FD & $48 \mathrm{~h}$ & 428 & 642 & 33.7 & 46.5 & $2.9-5.5$ \\
SAS 2 PW-FD (LF) & None & 443 & 609 & 39.5 & 47.4 & $5.1-6.7$ \\
SAS 2 PW-FD (LF) & $8 \mathrm{~h}$ & 466 & 647 & 29.8 & 44.2 & $2.4-3.7$ \\
SAS 2 PW-FD (LF) & $48 \mathrm{~h}$ & 444 & 657 & 31.4 & 51.2 & $1.9-2.3$ \\
E 347 H PW-FD & None & 410 & 575 & 41.7 & 63.7 & $4.3-5.8$ \\
E 347 H PW-FD & $8 \mathrm{~h}$ & 415 & 608 & 36.7 & 49.6 & $2.2-3.3$ \\
E 347 H PW-FD & $48 \mathrm{~h}$ & 433 & 644 & 31.5 & 42.8 & $1.8-2.2$ \\
\hline
\end{tabular}


were examined in a Tescan W-SEM Vega 3.0 scanning electron microscope (SEM) with Oxford Instruments X$\operatorname{Max}^{\mathrm{N}} 50$ to carry out energy dispersive spectroscopy (EDS).

Modified Varestraint testing was performed on $100 \times 40 \times 10 \mathrm{~mm}$ all-weld metal samples in accordance with ISO/TR 17641-3:2005. A single weld was made with the GTAW process in the centre of each sample along its $100 \mathrm{~mm}$ length. Pure argon was used as shielding gas and the welding speed was $3 \mathrm{~mm} / \mathrm{s}$. The displacement rate was held constant at $2 \mathrm{~mm} / \mathrm{s}$ (fairly slow). Further parameters are given in Table 4.

Overlay welding was performed on ASTM A387 Grade 22 (10CrMo9-10) using E 309L H-FD for the first layer and E 347L H-FD for the second. The shielding gas used was $\mathrm{Ar}+18 \% \mathrm{CO}_{2}$, and the welding position was flat $1 \mathrm{G} / \mathrm{PA}$. The overlapping was about $50 \%$, and the interpass temperature was held below $150{ }^{\circ} \mathrm{C}$. The welding parameters used were 240-245 A, 28.8-29.1 V and $12 \mathrm{~m} / \mathrm{min}$ wire feeding rate. The test was repeated using E 309L H PW-FD as buffer layer and E $347 \mathrm{H} \mathrm{PW-FD} \mathrm{as} \mathrm{second} \mathrm{layer.} \mathrm{The}$ interpass temperature was $150{ }^{\circ} \mathrm{C}$ and the current $210 \mathrm{~A}$ with $10 \mathrm{~m} / \mathrm{min}$ wire feed speed. The total resulting layer height was $5.0-6.5 \mathrm{~mm}$. The wires for welding out of position were also tested in flat position (1G/PA) and vertical up $(3 \mathrm{G} / \mathrm{PF})$. Good welding characteristics were obtained in the flat position using $12 \mathrm{~m} / \mathrm{min}$ wire feeding and 240-250 A. In the vertical up position, $8 \mathrm{~m} / \mathrm{min}$ wire feeding and 160-170 A were used.

\section{Results and discussion}

\subsection{All-weld metal}

Tables 5 and 6 show mechanical test results for all-weld metal samples. The wires had more or less the same strength, but the elongation values were higher for the bismuth-free wires. The impact toughness and lateral expansion were significantly greater for the bismuth-free versions than for the standard material.

The hot tensile test results are given in Table 7. At $700{ }^{\circ} \mathrm{C}$, a typical PWHT temperature when overlay welding creep-resistant steels, the conventional wires showed a dramatic decrease in elongation values. This ductility loss demonstrates the effect of bismuth at high temperature. On the contrary, the hot tensile tests performed at $500{ }^{\circ} \mathrm{C}$ did not show significant differences between the wires regardless of bismuth content. This confirms that the temperature limit of $500{ }^{\circ} \mathrm{C}$ stated by AWS A5.22/A5.22M:2012 for bismuth-alloyed wires is suitable. The hot tensile tests performed with the bismuth-free E $308 \mathrm{H} \mathrm{PW}-\mathrm{FD}$ wire still showed high elongation at both $700{ }^{\circ} \mathrm{C}$ and $800{ }^{\circ} \mathrm{C}$, which are typical service temperatures in, e.g. the $\mathrm{FCC}$ regeneration process.

The mechanical properties for the E347 type T0 fillers are found in Table 8. The ultimate tensile strength increased somewhat with PWHT and the elongation decreased. The impact toughness and lateral
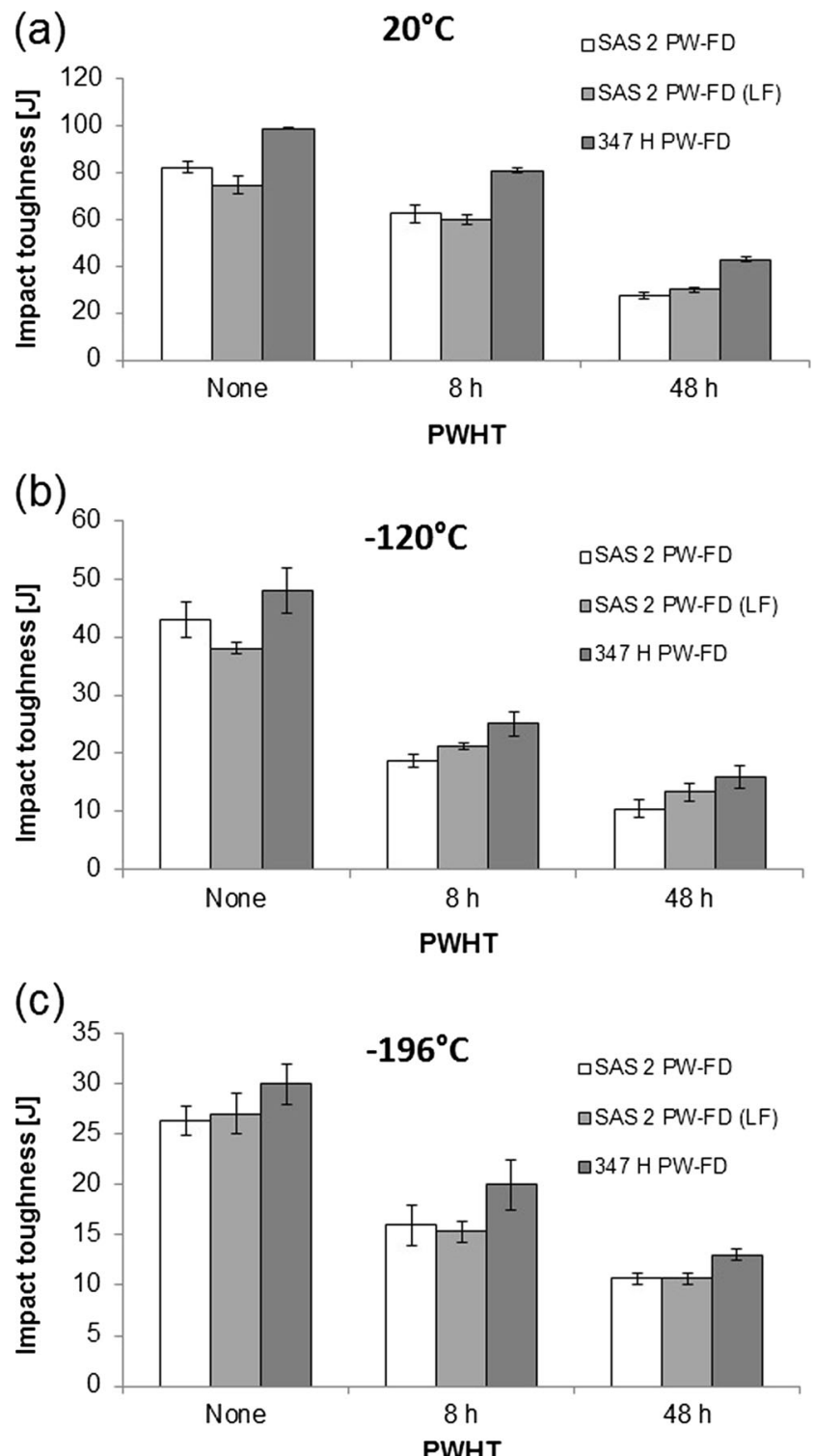

Fig. 1 Impact toughness testing of as-welded material and after PWHT at $700{ }^{\circ} \mathrm{C}$ for 8 and $48 \mathrm{~h}$ at $\mathbf{a} 20, \mathbf{b}-120$ and $\mathbf{c}-196^{\circ} \mathrm{C}$ 
expansion were slightly better with the bismuth-free wire. The E 347L H-FD showed somewhat higher impact toughness also in the as-welded condition. This is believed to be related to the weld metal oxygen content resulting from the different slag concepts. Inert gas fusion analysis for oxygen determination (LECO TCH600O) confirmed that E 347L H-FD had 0.079 wt.\% oxygen as compared with 0.094 wt.\% in SAS 2-FD.

Table 9 shows the mechanical properties of the E347 type T1 wires and Fig. 1 gives the impact toughness. The tensile strength increased somewhat after PWHT and the ferrite content and elongation decreased. The impact toughness was higher for the bismuth-free wire and remained higher also after PWHT.

Table 10 summarises the Varestraint test results of the E347 type fillers with and without bismuth after a PWHT for $40 \mathrm{~h}$ at $705{ }^{\circ} \mathrm{C}$. None of the materials were sensitive to hot cracking, and no solidification or reheat cracks were found in the weld metal. The bismuth-free weld metal showed no cracking regardless of strain level. The bismuth-containing samples, however, showed cracks in the HAZ and ductility dip cracking at the highest strain of $4 \%$. The distinction of ductility dip cracks from solidification cracks in the HAZ was that the former were not tied in with the fusion line. It needs to be pointed out that such high strain is mainly used for research purposes and not to simulate real conditions. PWHT did not appear to have any further effect on the hot cracking susceptibility. The total crack length in the HAZ was $0.13-0.24$ and $0.40-0.49 \mathrm{~mm}$ for ductility dip cracks. This is consistent with work by
Tsukimoto et al. [5] on E308H weld metal showing $0.35 \mathrm{~mm}$ max crack length with and without PWHT, respectively, in the $\mathrm{HAZ}$ for deposits containing $200 \mathrm{ppm} \mathrm{Bi}$ and no cracks for the Bi-free after solution annealing treatment $\left(1 \mathrm{~h}\right.$ at $1050{ }^{\circ} \mathrm{C}$ followed by water quenching). EPMA and Auger electron spectroscopy (AES) performed on fracture surfaces after creep testing confirmed that there is bismuth segregation in the grain boundary surface. Nishimoto et al. [13] studied the effect of bismuth on reheat cracking susceptibility in E308H weld metal. It was concluded that the bismuthcontaining weld metal had lower high-temperature ductility than bismuth-free weld metal, and it was suggested that bismuth segregation is responsible for reheat cracking at temperatures around $700{ }^{\circ} \mathrm{C}$. Cracks were found to propagate along columnar grain boundaries and/or ferrite/austenite boundaries. AES performed on these fracture surfaces showed the presence of bismuth and $\mathrm{X}$-ray diffraction analysis on electrochemically extracted residue detected $\mathrm{Bi}_{2} \mathrm{O}_{3} \cdot \mathrm{Bi}_{2} \mathrm{O}_{3}$ has the melting point of $820{ }^{\circ} \mathrm{C}$, and the authors suggested that grain boundary liquation occurs above this temperature due to melting of bismuth oxide. At lower temperature, bismuth is proposed to decrease the grain boundary strength by segregating on dendrite or grain boundaries and thus cause ductility-dip cracking.

The difference between the different hot tensile fracture surfaces was found to be small when examining them in a SEM, but the bismuth-alloyed wire SAS 2FD showed somewhat more brittle behaviour than the Bi-free wire E 347L H-FD (Fig. 2). EDS was not able

Table 10 Varestraint test crack evaluation with amount and total crack length of solidification/reheat cracks in HAZ and ductility dip cracking (DDC)

\begin{tabular}{|c|c|c|c|c|c|c|c|}
\hline \multirow[t]{2}{*}{ All-weld metal } & \multirow[t]{2}{*}{ PWHT } & \multicolumn{2}{|c|}{ Bend parameters } & \multicolumn{2}{|c|}{ Reheat cracks in HAZ } & \multicolumn{2}{|l|}{ DDC } \\
\hline & & Radius (mm) & Strain $(\%)$ & Amount & Total length (mm) & Amount & Total length (mm) \\
\hline SAS 2-FD & None & 500 & 1 & 0 & 0 & 0 & 0 \\
\hline SAS 2-FD & None & 250 & 2 & 0 & 0 & 0 & 0 \\
\hline SAS 2-FD & None & 125 & 4 & 4 & 0.24 & 6 & 0.49 \\
\hline SAS 2-FD & $705^{\circ} \mathrm{C}$ for $40 \mathrm{~h}$ & 500 & 1 & 0 & 0 & 0 & 0 \\
\hline SAS 2-FD & $705^{\circ} \mathrm{C}$ for $40 \mathrm{~h}$ & 250 & 2 & 0 & 0 & 0 & 0 \\
\hline SAS 2-FD & $705^{\circ} \mathrm{C}$ for $40 \mathrm{~h}$ & 125 & 4 & 2 & 0.13 & 1 & 0.40 \\
\hline E 347L H-FD & None & 500 & 1 & 0 & 0 & 0 & 0 \\
\hline E 347L H-FD & None & 250 & 2 & 0 & 0 & 0 & 0 \\
\hline E 347L H-FD & None & 125 & 4 & 0 & 0 & 0 & 0 \\
\hline E 347L H-FD & $705^{\circ} \mathrm{C}$ for $40 \mathrm{~h}$ & 500 & 1 & 0 & 0 & 0 & 0 \\
\hline E 347L H-FD & $705^{\circ} \mathrm{C}$ for $40 \mathrm{~h}$ & 250 & 2 & 0 & 0 & 0 & 0 \\
\hline E 347L H-FD & $705^{\circ} \mathrm{C}$ for $40 \mathrm{~h}$ & 125 & 4 & 0 & 0 & 0 & 0 \\
\hline
\end{tabular}

No solidification/reheat cracks were found in the weld metal 

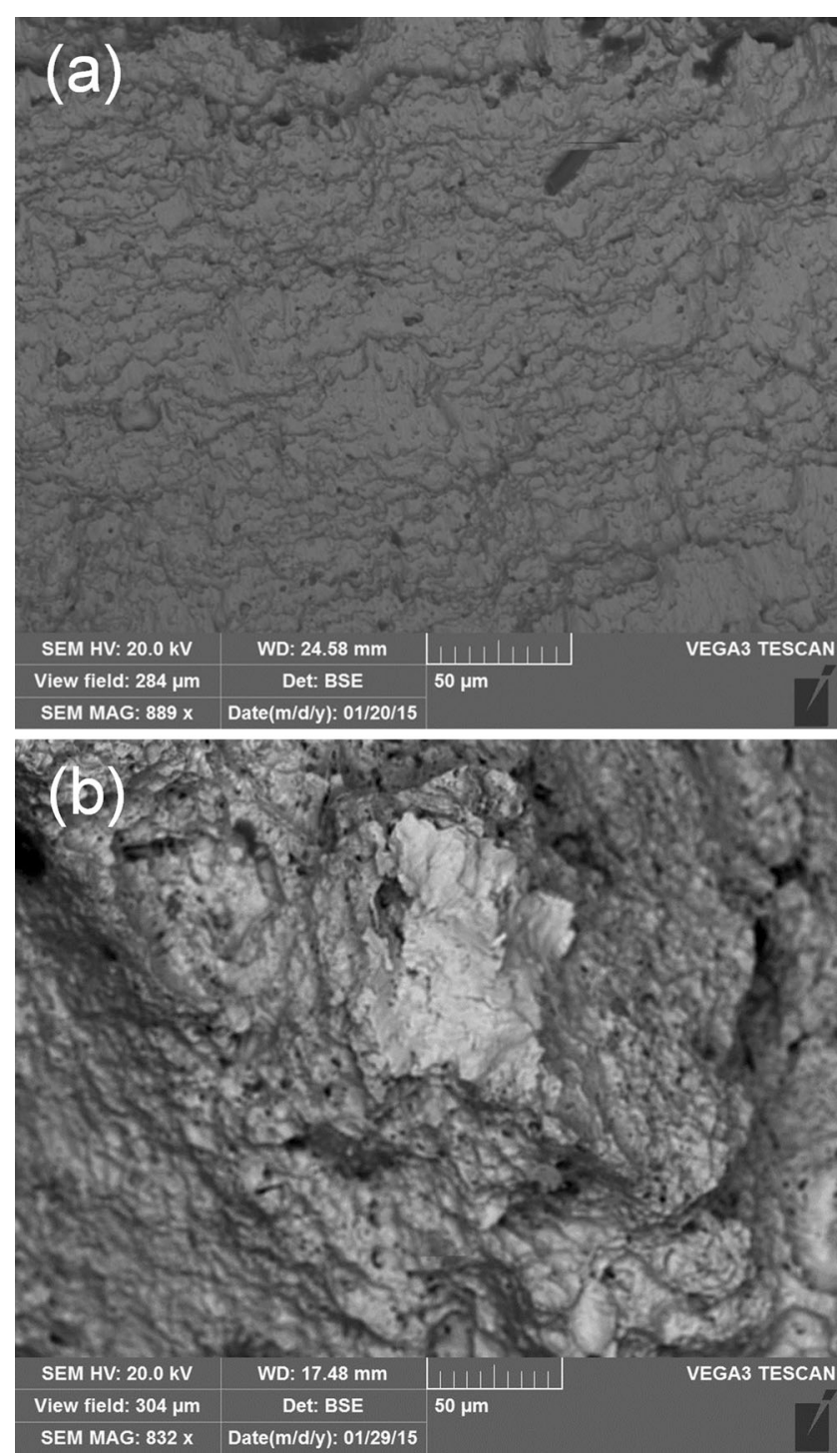

Fig. 2 SEM images of the fracture surface of hot tensile test specimens. a SAS 2-FD and b E 347L H-FD

to detect any $\mathrm{Bi}$ or $\mathrm{Bi}_{2} \mathrm{O}_{3}$ segregation on these fracture surfaces.

The results from the EPMA mapping of E347H type all-weld metal after PWHT can be found in Figs. 3 and 4. The element distribution indicates that the solidification was ferritic with chromium being concentrated in the dendrite cores and nickel interdendritically. The oxygen distribution in particles is mainly correlated to manganese, and there is no clear relation between bismuth and oxygen. In a prescreening, it was seen that the oxygen distribution is also related to silicon. Such inclusions are to be expected in the weld metal with a slag-bearing welding process. Bismuth was found in particle-like form in the SAS 2FD sample. The bismuth signal (Bi M $\alpha 1)$ does not appear to be disturbed by any niobium lines as there is no systematic bismuth content in the niobium-rich particles assumed to be niobium carbides. It is possible that the niobium carbides served as nuclei for the final bismuth precipitation and that the variation over the surface depends on how the sample was cut. When there were measurable amounts of bismuth, the microprobe analyser was able to detect it and the X-ray signal was significantly higher than the background value. The estimated measurement error is about $\pm 0.01 \%$ for bismuth.

\subsection{Welding in single V-butt weld joints}

The mechanical properties of standard and bismuth-free wires welded in a single V-butt weld joint are shown in Table 11. The actual joints confirmed that the impact toughness was significantly higher for the bismuth-free wires already in the as-welded condition. This is believed to be related to the difference in slag system - the bismuth-free weld metal results in lower weld metal oxygen levels.

\subsection{Overlay welding}

The resulting compositions from overlay welding in the flat position are shown in Tables 12 and 13. The slag detachability on the first layer with E 309L H-FD was fully satisfactory (Fig. 5). The dye-penetrant test performed afterwards did not show any indications of cracks or irregularities (Fig. 6). The slag removal of E 347L H-FD for the second layer was similar to that of E 309L H-FD (Fig. 7). Both wires resulted in very nice beads with uniform solidification lines on the surface. The bead appearance was on par with that of standard bismuthalloyed wires and there was no spatter formation when welding in spray arc mode. The same type of test with the all-position T1 wires showed similar results. The weldability and slag removal of the bismuth-free wires were comparable with that of the standard wires. The only difference was that the bead appearance was slightly more irregular due to the fast-freezing slag, but this is normal for T1 type wires.

\section{Conclusions}

Bismuth-free austenitic stainless steel flux-cored wires have been compared here with conventional wires for welding and overlay welding. The bismuth content is below $10 \mathrm{ppm}$ and fulfils the requirement of $20 \mathrm{ppm}$ max in the weld deposit as stated by AWS A5.22/A5.22M:2012 and API RP 582. The bismuth-free wires showed improved resistance to embrittlement after PWHT at $700{ }^{\circ} \mathrm{C}$, and the impact toughness and lateral expansion values were higher than for wires containing $180 \mathrm{ppm}$ bismuth. Hot tensile tests performed at temperatures typical for service or PWHT confirmed significantly better elongation values for the bismuth-free wires as compared with 

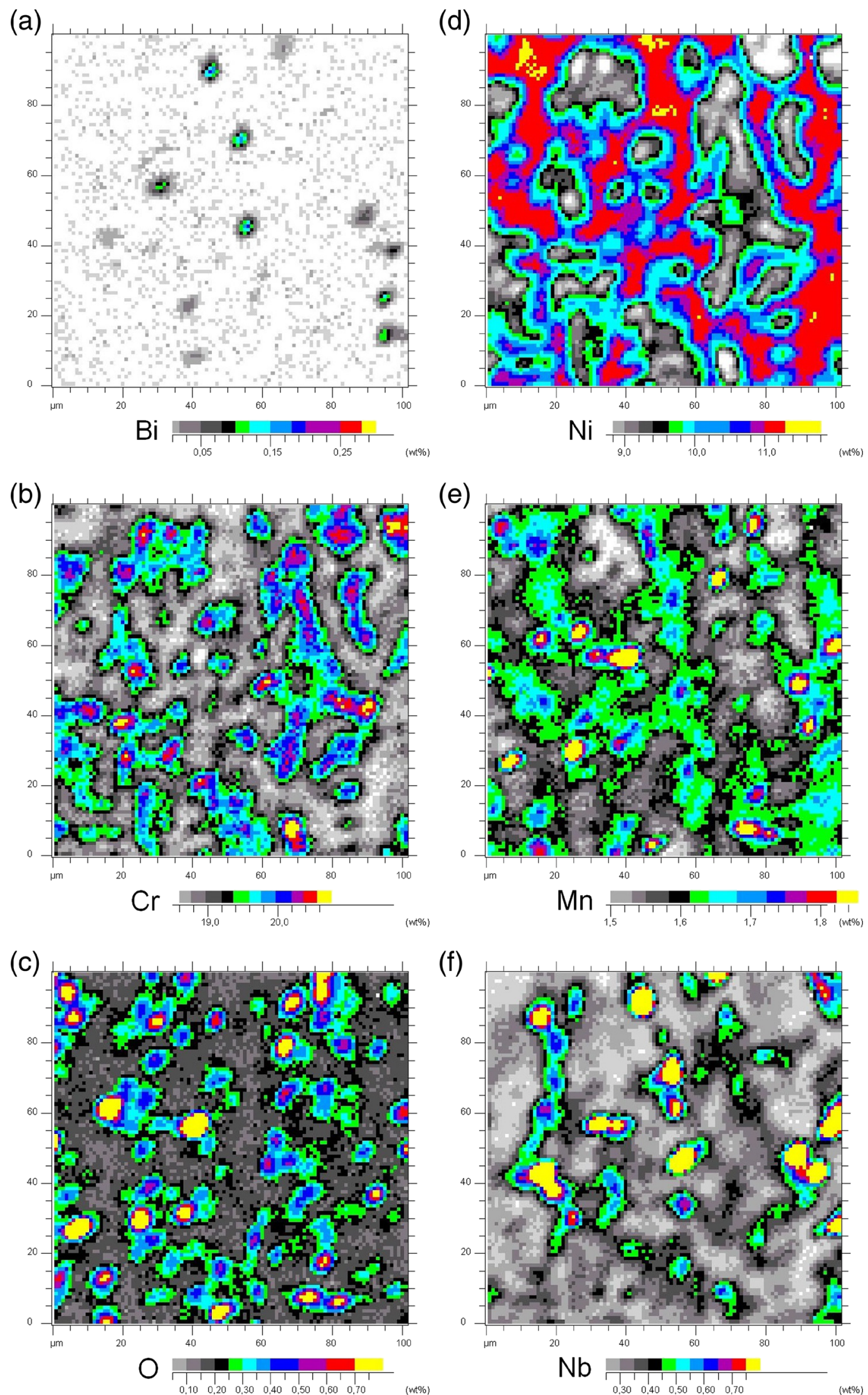

Fig. 3 Element distribution in EPMA mapping of SAS 2-FD all-weld metal containing bismuth 
(a)

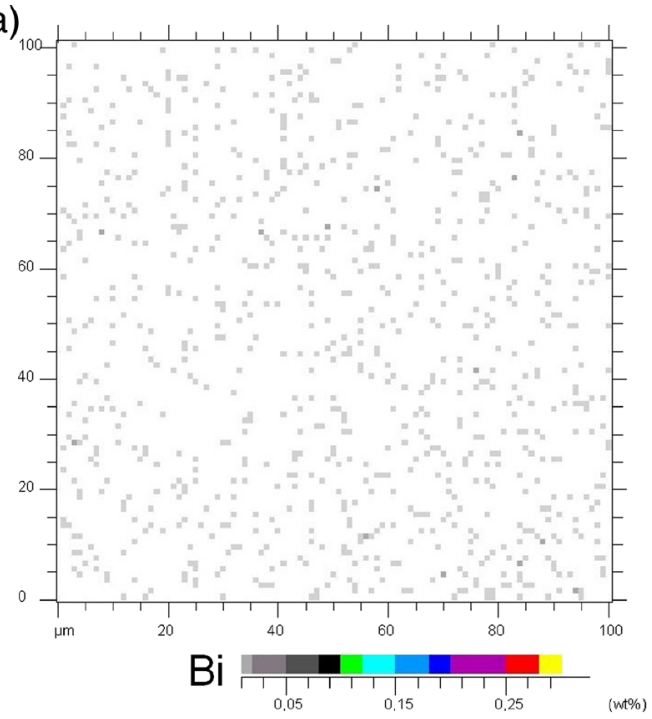

(b)

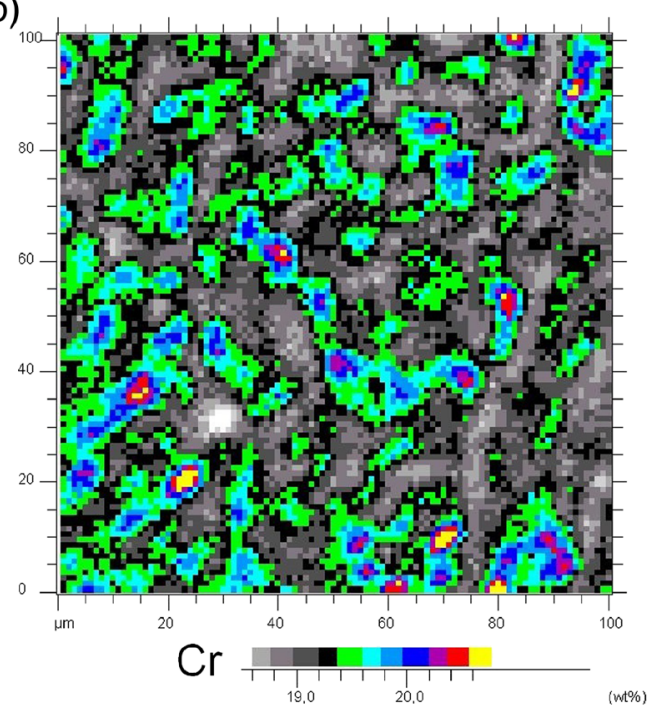

(c)

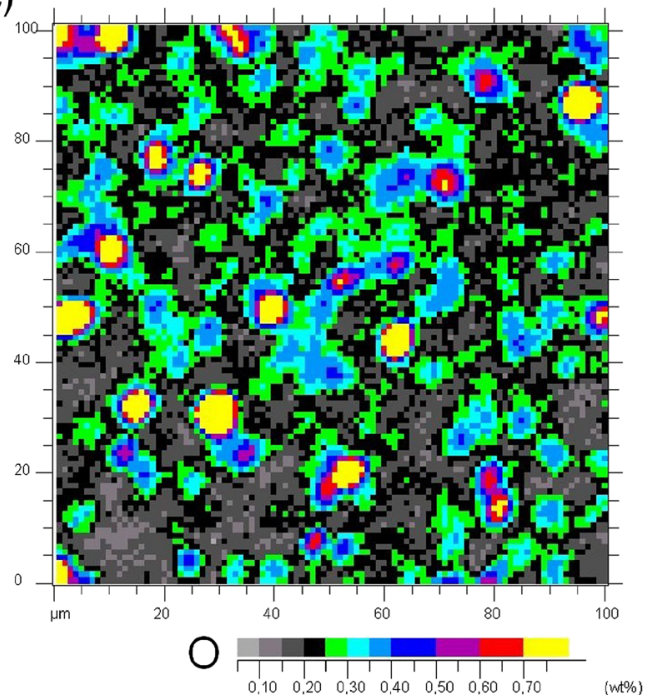

(d)

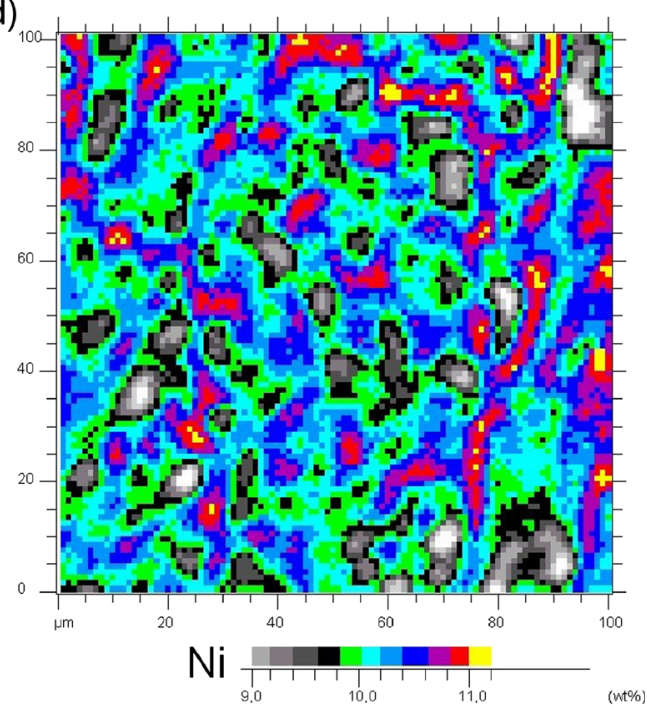

(e)

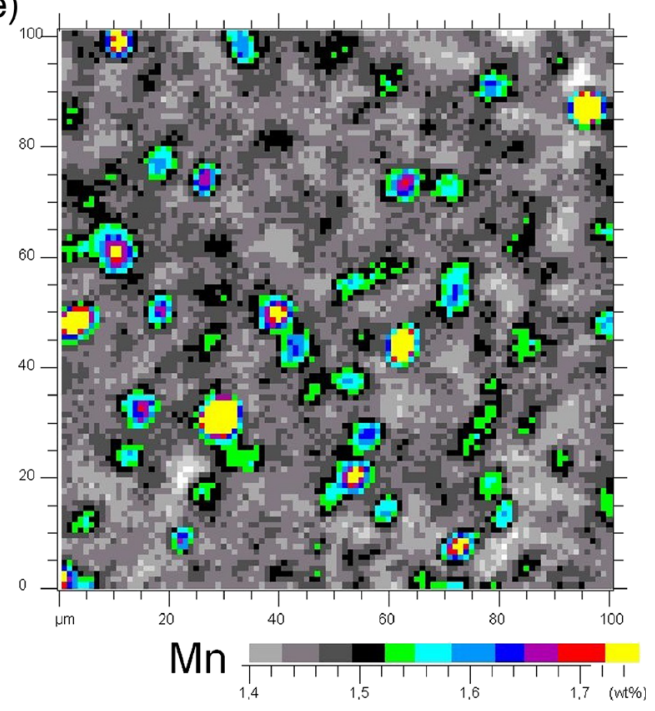

(f)

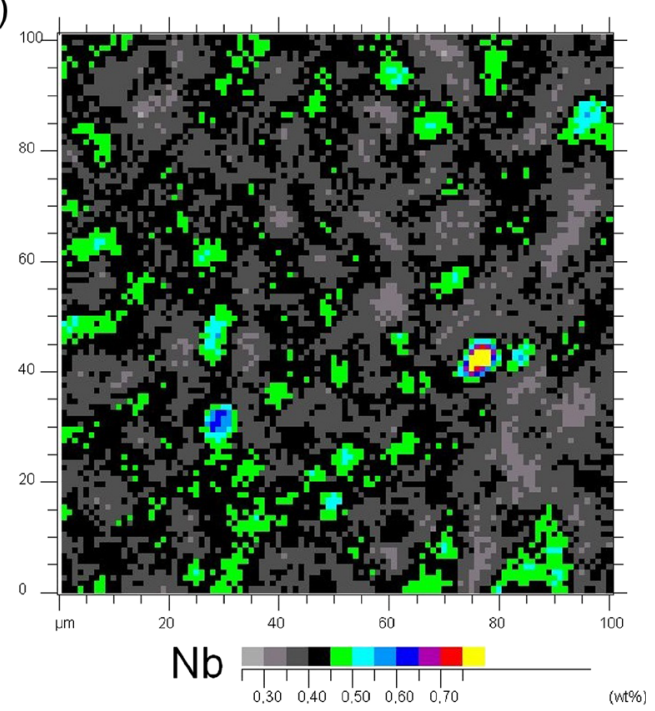

Fig. 4 Element distribution in EPMA mapping of bismuth-free E 347L H-FD all-weld metal 
Table 11 Mechanical properties of $\mathrm{V}$ joints in as-welded condition

\begin{tabular}{|c|c|c|c|c|c|c|c|c|}
\hline \multirow[t]{2}{*}{ Filler } & \multicolumn{4}{|c|}{ Tensile test } & \multicolumn{4}{|c|}{ Impact toughness $(\mathrm{J})$} \\
\hline & $\begin{array}{l}\mathrm{Rp}_{0.2} \\
(\mathrm{MPa})\end{array}$ & $\begin{array}{l}\mathrm{Rm} \\
(\mathrm{MPa})\end{array}$ & $\begin{array}{l}\mathrm{A}_{5} \\
(\%)\end{array}$ & $\begin{array}{l}Z \\
(\%)\end{array}$ & $20^{\circ} \mathrm{C}$ & $-60^{\circ} \mathrm{C}$ & $-120^{\circ} \mathrm{C}$ & $-196^{\circ} \mathrm{C}$ \\
\hline SAS 2 PW-FD & 430 & 598 & 39.2 & 61.6 & $82 \pm 3$ & & $45 \pm 6$ & $26 \pm 2$ \\
\hline E 347 H PW-FD & 417 & 587 & 41.8 & 57.1 & $101 \pm 2$ & & $49 \pm 2$ & $44 \pm 4$ \\
\hline $\begin{array}{l}\text { CN 23/12 PW- } \\
\text { FD }\end{array}$ & 412 & 557 & 39.0 & 58.3 & $64 \pm 2$ & $50 \pm 3$ & & \\
\hline $\begin{array}{l}\text { E 309L H PW- } \\
\text { FD }\end{array}$ & 412 & 558 & 41.8 & 52.6 & $87 \pm 6$ & $71 \pm 6$ & & \\
\hline
\end{tabular}

Table 12 Measured composition of the first and second layer performed with T0 wires (wt.\%)

\begin{tabular}{llllllllll}
\hline Filler & Layer & $\mathrm{C}$ & $\mathrm{Si}$ & $\mathrm{Mn}$ & $\mathrm{Cr}$ & $\mathrm{Ni}$ & $\mathrm{Mo}$ & $\mathrm{Nb}$ & Ferrite \\
\hline E 309L H-FD & 1 & 0.048 & 0.529 & 1.3 & 19.8 & 10.33 & 0.148 & $<0.004$ & $8.9 \mathrm{FN}$ \\
E 347L H-FD & 2 & 0.034 & 0.593 & 1.49 & 19.28 & 10.21 & 0.083 & 0.39 & $6.5-7.5 \mathrm{FN}$ \\
\hline
\end{tabular}

Table 13 Measured composition of the first and second layer performed with $\mathrm{T} 1$ wires (wt.\%)

\begin{tabular}{llllllllll}
\hline Filler & Layer & $\mathrm{C}$ & $\mathrm{Si}$ & $\mathrm{Mn}$ & $\mathrm{Cr}$ & $\mathrm{Ni}$ & $\mathrm{Mo}$ & $\mathrm{Nb}$ & Ferrite \\
\hline E 309L H PW-FD & 1 & 0.042 & 0.743 & 1.21 & 23.56 & 12.48 & 0.034 & $<0.004$ & $9.3 \mathrm{FN}$ \\
E 347 H PW-FD & 2 & 0.044 & 0.712 & 1.46 & 18.52 & 10.55 & 0.082 & 0.424 & $6.1 \mathrm{FN}$ \\
\hline
\end{tabular}

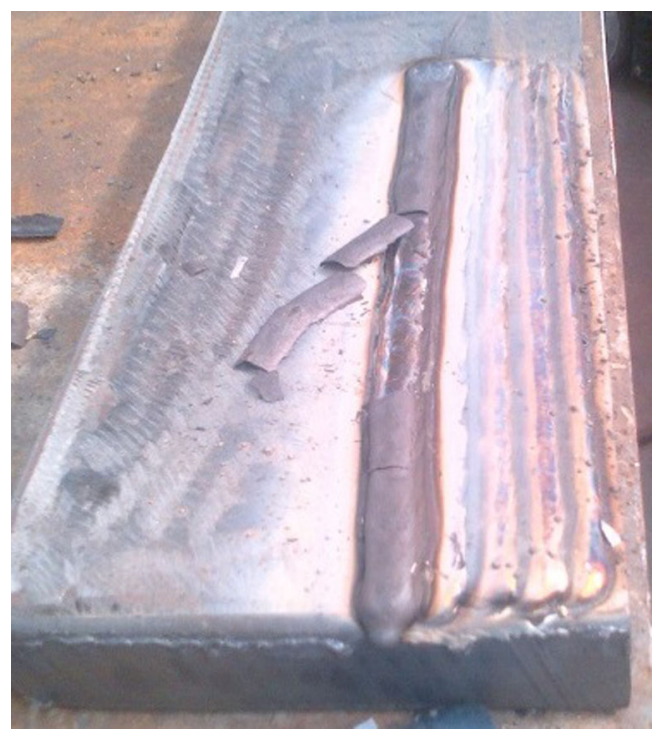

Fig. 5 First-layer cladding with E 309L H-FD showing good slag detachability

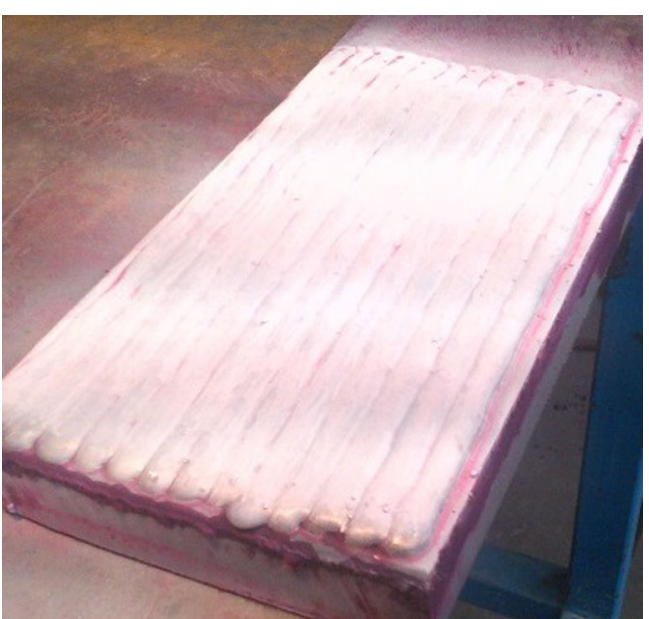

Fig. 6 Dye-penetrant test after first layer of E 309L H-FD. No indication of cracks or porosity 


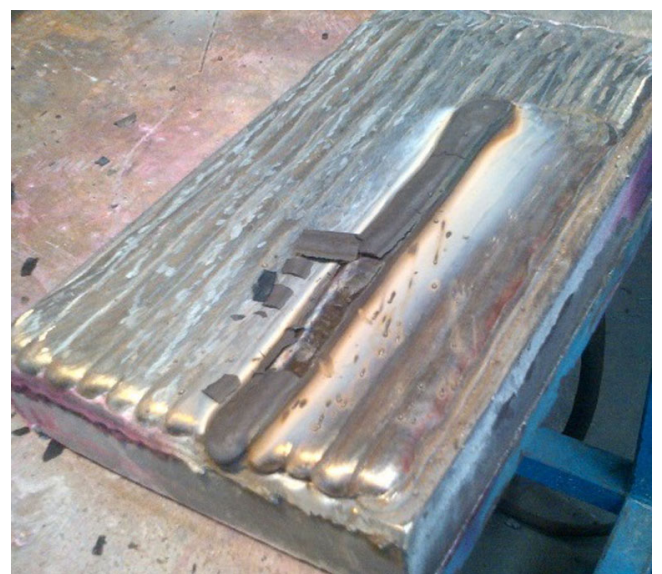

Fig. 7 The second E 347L H-FD layer showed slag removal similar to that of the first layer

the conventional wires. The results support that grain boundary bismuth segregation is responsible for the decreased ductility in bismuth-containing weld metal after PWHT at $700{ }^{\circ} \mathrm{C}$. EPMA mapping showed that bismuth is present with a particle-like distribution without any clear relation to oxygen, but niobium.

Acknowledgements Open access funding provided by Montanuniversität Leoben. Dr. Kochubey Vadym at voestalpine Böhler Welding Germany GmbH, Hamm, Germany carried out the SEM fracture surface analysis. Dr. Anton Holy at voestalpine Böhler Welding Austria $\mathrm{GmbH}$, Kapfenberg, Austria prepared the EPMA samples. The Varestraint testing was performed at the Federal Institute for Materials Research and Testing in Berlin, Germany. Dr. C.E. Cross at Los Alamos National Laboratory, Los Alamos, New Mexico, USA gave valuable comments on the script.

Open Access This article is distributed under the terms of the Creative Commons Attribution 4.0 International License (http:// creativecommons.org/licenses/by/4.0/), which permits unrestricted use, distribution, and reproduction in any medium, provided you give appropriate credit to the original author(s) and the source, provide a link to the Creative Commons license, and indicate if changes were made.

\section{References}

1. Farrar JCM, Marshall AW, Zhang Z (2001) Position statement on the effect of bismuth on the elevated temperature properties of fluxcored stainless steel weldments. Weld World 45(5/6):25-31

2. Chemical Plant Welding Research Committee of the Japan Engineering Society (JWES) (1996) High temperature damage to stainless steel welds made by flux-cored arc welding and its analysis. Proceedings, API 61th Fall Refinery Meeting, pp. 21-23

3. Nishiyama S, Mashushita Y, Maruyama T (1995) Flux-cored wires for stainless steel welding. Weld World 36:103-123

4. Hara Y et al. (1996) High temperature damage to stainless steel welds made by flux cored arc welding and its analysis. Proc. API 61st Full Refinery Meeting, Houston, TX

5. Nishimoto K, Matsunaga T, Tanaka T, Okazaki T (1998) Effect of bismuth on reheat cracking susceptibility in type 308 FCAW weld metal. Weld World 41:220-235

6. Konosu S, Hashimoto A, Mashiba H, Takeshima T, Ohtsuka T (1998) Creep crack growth properties of type 308 austenitic stainless steel weld metals. Weld J 77(8):22s-327s

7. Kotecki D (March 2008) Weld J Stainless Q\&A, p. 54

8. Marshall AW, Farrar JCM (1999) Type '308H' austenitic stainless steel weld metals for high temperature service. Proc. Stainless Steel World '99 Conference, The Hague, The Netherlands, pp. 147-162.

9. American Petroleum Institute Recommended Practice, API RP 582 (2009) "Welding Guidelines for the Chemical, Oil, and Gas Industries", 2nd Edition, 14 pp.

10. AWS A5.22/A5.22M:2012. Specification for stainless steel flux cored and metal cored welding electrodes and rods. A8.1.4 Bismuth (Bi) in Flux Cored Stainless Steel Electrodes, 55 pp.

11. Godrej Process Equipment Division specification (2008) Welding engineering, WCPS for SMAW consumables and FCAW wire. WCPS/130615-130641, 3 pp.

12. Grönlund K, Runnsjö G (2002) An electron micro/macro probe system for elemental concentration mapping. CETAS Conference on Progress of Analytical Chemistry, Luxembourg

13. Tsukimoto K, Tozoda M, Marsumoto O, Kawaguchi S (1998) Effect of elements on weldability and hot ductility of FCAW stainless steel weld metal. Weld World 41:240-252 